\title{
PERANAN GURU DALAM MENGHADAPI PENGARUH NEGATIF PENGGUNAAN INTERNET
}

\author{
Fitriana Destiawati, Harry Dhika, Aulia Paramita \\ Universitas Indraprasta PGRI \\ *honeyzone86@gmail.com
}

\begin{abstract}
The introduction of the internet to children from an early age is one of the factors that will affect the progress of a nation in the future, however with the development of technology there will be both positive and negative impacts. In this study, the socialization of the role of early childhood teachers in dealing with the negative effects of internet use on children aims to provide convenience in using technology, especially the internet, on children's development. The results of this study are to provide an understanding of the positive and negative impacts of internet use on early childhood students, knowing its implementation is expected to provide ease in using current technology.
\end{abstract}

Keywords: Negative Influences, Children, Internet

\begin{abstract}
Abstrak
Pengenalan internet kepada anak-anak sejak dini merupakan salah satu faktor yang akan mempengaruhi majunya suatu bangsa di masa depan, akan tetapi dengan adanya perkembangan teknologi akan ada dampak positif dan negatifnya. Pada kajian ini sosialisasi peranan guru PAUD dalam menghadapi pengaruh negatif penggunaan internet terhadap anak yang bertujuan untuk memberikan kemudahan dalam penggunaan teknologi khususnya internet terhadap perkembangan anak. Hasil dari penelitian ini adalah memberikan pemahaman dalam dampak positif dan negatif dari penggunaan internet pada anak didik usia dini, dengan mengetahui implementasinya diharapkan dapat memberikan kemudahan dalam penggunaan teknologi saat ini.
\end{abstract}

Kata Kunci: Pengaruh Negatif, Anak, Internet

Submitted: 2021-05-18

Revised: 2021-07-26

Accepted: 2021-07-31

\section{Pendahuluan}

Perkembangan teknologi informasi telah membawa dampak yang luar biasa bagi kehidupan manusia. Dampak dari perkembangan tersebut adalah tiadanya batas-batas ruang dan waktu. Apa saja yang terjadi di wilayah daerah bahkan negara lain, baik yang di kota maupun desa, kini dapat dengan mudah diikuti baik langsung maupun tidak langsung. Berkat kemajuan teknologi, terutama teknologi komunikasi segalanya menjadi sangat mudah. Selain itu pengenalan internet kepada anak-anak sejak dini juga salah satu faktor yang akan mempengaruhi maju tidaknya suatu bangsa di masa depan. Salah satu kemajuan teknologi adalah teknologi informasi internet (Febrino, 2017). Teknologi informasi akan banyak digunakan di masa mendatang, banyak orang tua yang memperkenalkan teknologi informasi dan komunikasi kepada anak-anaknya khususnya internet. Pengetahuan akan materi pembelajaran dan pembahasanya ada semua di internet hal ini dapat mempengaruhi perkembangan anak dalam kegiatan belajar mengajar. Terdapat dampak positif dan negatif dalam penggunaanya. Dampak positif yang ditimbulkan oleh internet antara lain untuk memudahkan surat menyurat, mengirim pesan, chatting, mengambil atau mengirim informasi dan sarana untuk hiburan (Sari et al., 2017).

Urgensi kegiatan yaitu maraknya penggunaan smartphone oleh anak sehingga orang tua dan guru wajib mengetahui dampak positif dan negative dari Smartphone. Tujuan pengabdian masyarakat ini adalah pendidik memperoleh pengetahuan tentang dampak negatif dan positif dari penggunaan smartphone oleh anak, sehingga Pendidik dapat menyampaikan hal tersebut kepada 
orang tua dan mengingatkan orang tua untuk tetap mengawasi anak ketika menggunakan smartphone/ gadget. Pendidik mengetahui manfaat penggunaan internet dari smartphone untuk dijadikan bahan materi pembelajaran yang lebih tepat untuk anak usia dini.

Adapun target dari pengabdian masyarakat ini adalah semua pendidik yang mengajar pada kedua mitra kami yatu PAUD Melati dan PAUD Dahlia, dari khalayak sasaran yang strategis tersebut diharapkan berbagai informasi yang diberikan dapat digunakan untuk meningkatkan kualitas pendidikan sehingga pengajaran yang dilakukan pendidik dapat lebih menarik dengan penggunaan internet, khususnya untuk anak-anak agar meningkatkan minat dalam belajar. Hasil dari pengabdian masyarakat ini merupakan pemahaman sosialisasi dalam penggunaan internet. Pelatihan kepada para pendidik tentang sosialisasi peranan pendidik PAUD dalam menghadapi pengaruh negatif penggunaan internet terhadap anak dan metodenya berupa teknik yang diberikan oleh tim pengabdian dalam memanfaatkan internet dan teknologi.

\section{Metode}

Pelaksanaan kegiatan pengabdian masyaralat yang dilaksanakan berbentuk sosialisasi kepada pendidik PAUD agar mendapatkan informasi mengenai beberapa layanan atau teknologi yang dapat membantu meminimalisir dampak buruk internet. Pelaksanaan kegiatan berlangsung selama 5 bulan dimulai dari persiapan proposal hingga pelaporan pertanggungjawaban kegiatan. Pelatihan dalam kegiatan pengabdian masyarakat pada kedua mitra dilaksanakan pada hari yang sama dan bertempat di Paud Melati. Partisipasi mitra dalam pelaksanaan program pengabdian masyarakat ini yakni sebagai objek yang menerima workshop atau lokasi dilakukannya sosialisasi, mitra dalam hal ini dikhususkan pada pendidik PAUD. Materi atau penyampaian sosialisasi tersebut diberikan pada pendidik yang ada pada PAUD Melati dan PAUD Dahlia.

Pelaksanaan dilakukan dengan tahapan kerja sebagai berikut: Observasi Kebutuhan, Pembuatan proposal kegiatan untuk membuhi kebutuhan (solusi), Pengajuan proposal kepada mitra, Persetujuan mitra, Pengajuan proposal kepada Lembaga, Terima Surat Tugas, Koordinasi pelaksanaan antara tim abdimas dan mitra, Pelaksanaan kegiatan, Pelaporan kegiatan.

Pelaksanaan kegiatan berlangsung selama 5 bulan dimulai dari persiapan proposal hingga pelaporan pertanggungjawaban kegiatan. Pelatihan dalam kegiatan pengabdian masyarakat pada kedua mitra dilaksanakan pada hari yang sama dan bertempat di Paud Melati. Berikut adalah jadwal kegiatan pelaksanaan pelatihan: Pembukaan, Sosialisasi, Pemberian beberapa tips untuk pencegahan dampak buruk internet, Penutup. Secara garis besar mirip dengan metode yang dilakukan oleh (Damanik \& Purba, 2021) mengenai pola pengabdian masyarakat yang dilakukan, yakni memberikan pendidikan pada masyarakat, pelayanan kepada masyarakat, penerapan hasil kajian, dan melakukan tindakan langsung tepat sasaran. Dalam kajian lain juga terkait penyuluhan ini memperhatikan tindakan yang dilakukan mirip dengan tindakan kelas seperti pada kajian yang dilakukan oleh (Nurgiansah, 2021) yakni mengenai planning, action, observation dan refleksi.

\section{Hasil dan Pembahasan}

Dalam memajukan kecerdasan bangsa dan idealisme Pancasila, maka diperlukan pendidikan karakter sejak dini. Bukan hanya anak-anak ditingkat Sekolah Dasar, Sekolah Menengah Atas, ataupun Sekolah Menengah Pertama, akan tetapi alangkah tepatnya dimulai sejak pendidikan usia dini. Penggunaan gadget dikalangan anak berdampak negatif terhadap perkembangannya (Warisyah, 2015). Urgensi pendidikan karakter sejak anak usia dini dimungkin karena perkembangan teknologi yang pesat. Salah satunya adalah hadirnya smartphone yang mudah terkoneksi internet dan mudah digunakan oleh pengguna anak-anak. Anak-anak senang 
memainkan smartphone. Hal ini dikarenak penyajiannya yang dinamis dan visual yang menarik sehingga anak-anak mudah mengerti dan banyak hal yang menarik dalam smartphone.

Hampir semua kalangan masyarakat memiliki gadget (Desa et al., 2018), dahulu gadget hanya bias digunakan untuk komunikasi, sedangkan saat ini ada banyak fungsi yang ditawarkan yaitu kamera, perekam video, peta digital, pemutar musik, jaringan internet, dan lain-lainnya. Selain itu banyak anak-anak yang menyukai menonton sesuatu dari smartphone yang ditampilkan oleh YouTube, TV online, dan lainnya. Salah satu teknologi yang dipakai dalam pendidikan yaitu internet (Dhahir, 2018). Saat ini informasi tentang berbagai belahan dunia dapat dijangkau dengan mudah oleh semua kalangan termasuk anak-anak melalui Smartphone. Kemampuan anak usia dini dalam menggunakan smartphone berfasilitas internet merupakan salah satu hal penting yang perlu dalam pengawasan, hal ini dimungkinkan banyak informasi yang seharusnya dibimbing oleh orang tua sehingga anak mengetahui informasi yang tepat dan tidak tepat untuk dipelajari. Kita ketahui budaya asing sudah masuk dengan mudah melalui intenet sehingga dapat menggeser nilai-nilai luhur yang seharusnya dipelajari dalam tumbuh kembang seorang anak. Walaupun informasi tentang budaya asing bukanlah hal yang salah, akan tetapi jika penerima informasi seorang anakanak maka sebaiknya orang tua atau guru mengawasi dan membimbing anak-anak dalam penggunaan internet.

Usia dibawah 6 tahun, anak masih pada masa bermain sehingga menggunakan Gadgetpun hanya untuk bermain dan membentuk pola pikir sesuai dengan apa yang dilihatnya. Selain itu pada usia 6 tahun perkembangan otak anak maningkat lebih cepat. Manfaat penggunaan Smartphone pada usia dini adalah meningkatkan kecepatan mempelajari sesuatu hal yang baru, dan belajar berkomunikasi. Akan tetapi ada resiko penggunaan Smartphone di usia dini menurit yaitu kecanduan gadget, anak menjadi pemalas, mobilitas sosial menurun, karena anak lebih focus pada gadget, kurang berkonsentarsi pad hal nyata, dikarena anak biasa melihat yang tidak nyata. Selain perkembangan sosial yang terganggu, ancaman informasi yang belum semestinya mereka dapatkan juga memberikan dampak luar bisa terhadap kejiwaan si anak tersebut (Khotijah, 2013). Solusi dalam menangani dampak negatif dari gadget yaitu dengan pendampingan dialog yang dilakukan oleh orang tua. Pendampingan dilakukan secara terus menerus. Anak sebaiknya tidak menggunakan gadget tanpa didampingi orang tua. Orang tua mendampingi anak dalam menggunakan gadget dengan mengarahkan anak untuk membuka fitur-fitur yang sesuai dengan tahap perkembangan anak. Salah satu caranya adalah dengan menyediakan peramban web khusus untuk anak-anak (Ulinnuha, 2013).

Adapun cara menanggulanginya adalah sebagai berikut:

1. Pendamping sangatlah dibutuhkan disinilh orang tua yang berperan. Penggunaan komputer atau gadget harus terbuka dan orang tua harus bisa melihat dan memantaunya.

2. Komputer harus berada di ruangan yang bersifaat umum sehingga dapat terus dipantau kegiatan anak saat mengakses internet.

3. Orang tua dan anak bersama-sama duduk di komputer dan tentukan jadwal online bersama sama, serta berdiskusi tentang berbagai informasi.

4. Biasakan anak untuk disiplin mematuhi batasan waktu dengan batasan yang sudah disepakati bersama dalam menggunakan internet.

5. Berikan pemahaman tentang manfaat positif dan negatif internet kepada anak.

6. Berikan pemahaman untuk tidak memberi data pribadi, tidak memberikan nomor telepon dan alamat serta tidak memberikan foto pada siapapun yang tidak dikenal.

7. Menggunakan internet protection software lokal untuk menghindarkan anak dari pengaruh negatif internet.

8. Biasakan untuk memberikan arahan bahwa bersosialisasi dengan lingkungan juga diperlukan supaya tidak kecanduan dengan internet. 


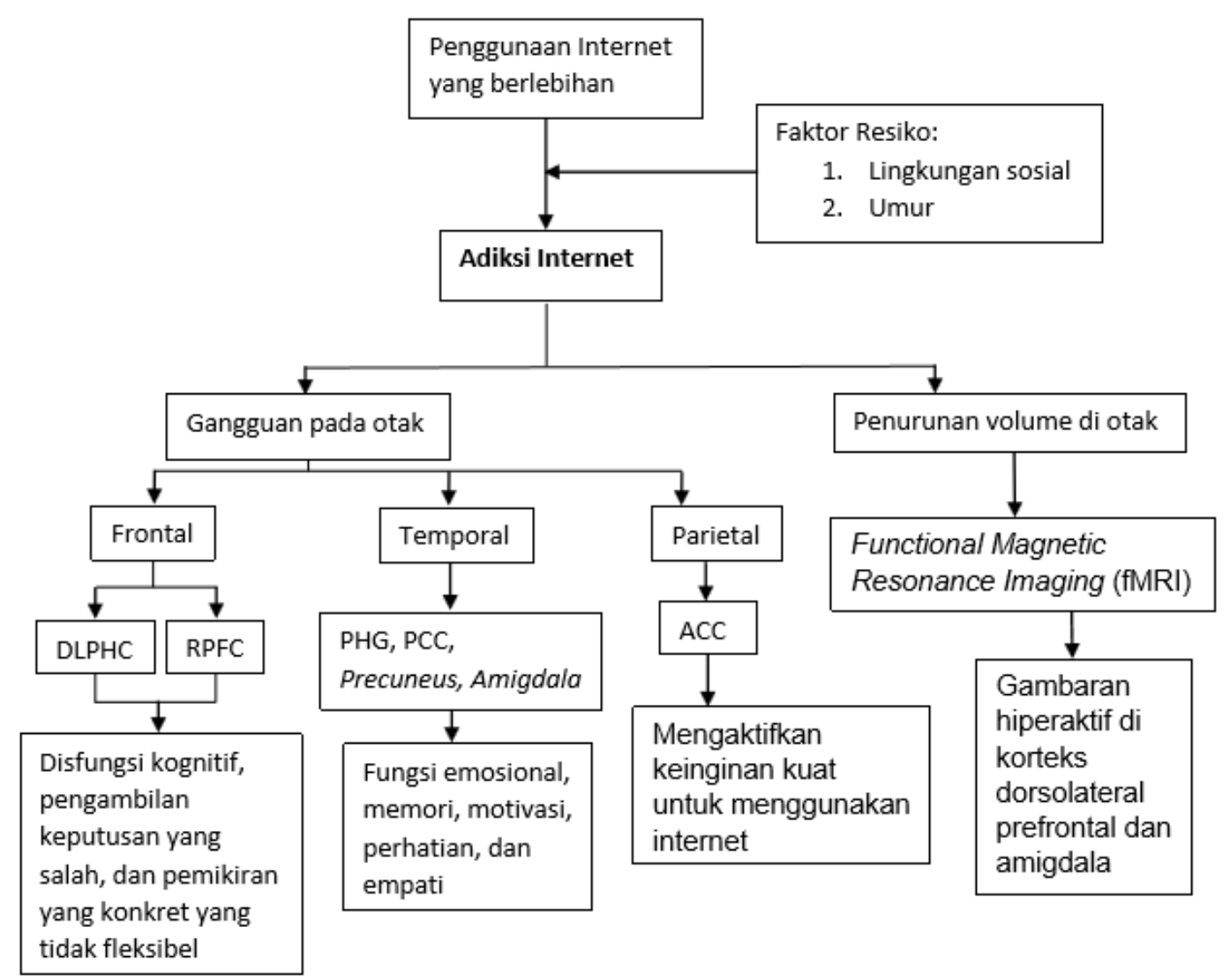

Gambar 1. Alur diagram adiksi internet (LEVANI et al., 2020)

Perilaku anak yang telah kecanduan layanan internet harus mendapat perhatian serius, selain dari para orang tua juga guru yang menjadi pendidik. Dalam hal ini, Guru PAUD (Pendidikan Anak Usia Dini) terutamanya mempunyai peran penting dalam membentuk karakter anak karena sejak usia dini nilai-nilai kehidupan mulai ditanamkan. Sumber daya manusia yang berkualitas merupakan bentuk masa depan bangsa, kemajuan sumber daya manusia yang dimiliki harus dibina sedini mungkin. Tumbuh perkembangan anak harus sudah diasuh dan dibimbing agar dapat berkembang sesuai apa yang diinginkan dikemudian hari. Anak pada usia 0-6 tahun kecerdasannyaa berkembang cepat sehingga perlu diberi stimultan yang tepat. Melalui pendidikan PAUD anak usia 0-6 tahun mendapat pembinaan watak dan karakter. 


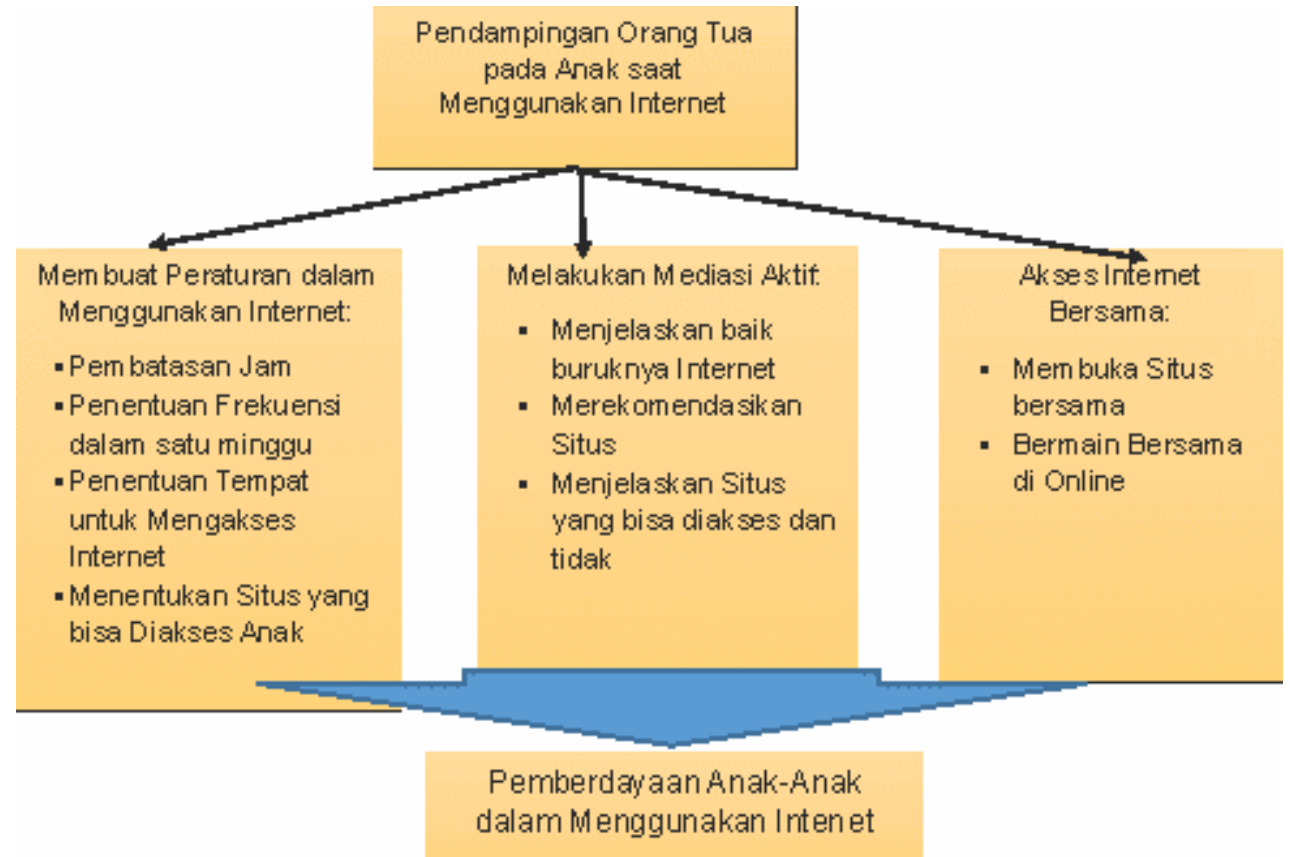

Gambar 2. Model Pendampingan dalam Menggunakan Internet (Claretta \& Arianto, 2018)

Berikut adalah hal-hal yang mendukung kerjasama mitra dan tim dalam mewujudkan kegiatan pengabdian masyarakat:

1. Sebelumnya sudah dijelaskan tentang hasil analisis situasi dari mitra yaitu pada umumnya mitra masih melakukan keiagatan belajar mengajar menggunakan bahan konvensional. Dan mitra memiliki kesadaran untuk mengetahui lebih banyak tentang teknologi dengan latar belakang banyaknya anak-anak yang sudah mahir dalam menggunakan internet dengan menggunakan Smartphone.

2. Kemampuan Tim dalam penggunaan teknologi.

3. Kerjasama Universitas dalam mewujudkan terlaksananya kegiatan secara adminitrasi surat menyurat, perlengkapan dan lainnya.

Sedangkan hambatan pelaksanaan kegiatan pengabdian masyarakat yaitu penentuan jadwal pelaksanaan karena bertepatan dengan Libur Hari Raya serta Kenaikan Kelas. Hambatan dalam kegiatan dapat diselesaikan dengan saling berkomunikasi sehingga dapat ditentukan waktu yang tepat. Hasil kegiatan yaitu:

1. Mitra mulai memahami tentang dampak positif dan negatif dari penggunaan internet pada anak didik usia dini.

2. Mitra mulai memahami tentang pentingnya pendampingan orang tua dalam penggunaan internet oleh anak, sehingga mitra menjadikan hal ini hal yang penting untuk disampaikan ke orangtua anak didik.

3. Mitra banyak mengajukan pertanyaan tentang bagaimana penggunaan yang tepat dari internet untuk anak dan situs-situs apa saja yang menyediakan informasi positif dan negatif.

4. Mitra mempelajari tentang pemanfaatan internet untuk memperoleh bahan materi ajar yang lebih inovatif dalam mendidik anak usia dini.

Mitra mempelajari tentang pengaruh penggunaan internet seperti Google dan Youtube oleh anak jika tidak diawasi oleh orang tua ataupun pendidik. 


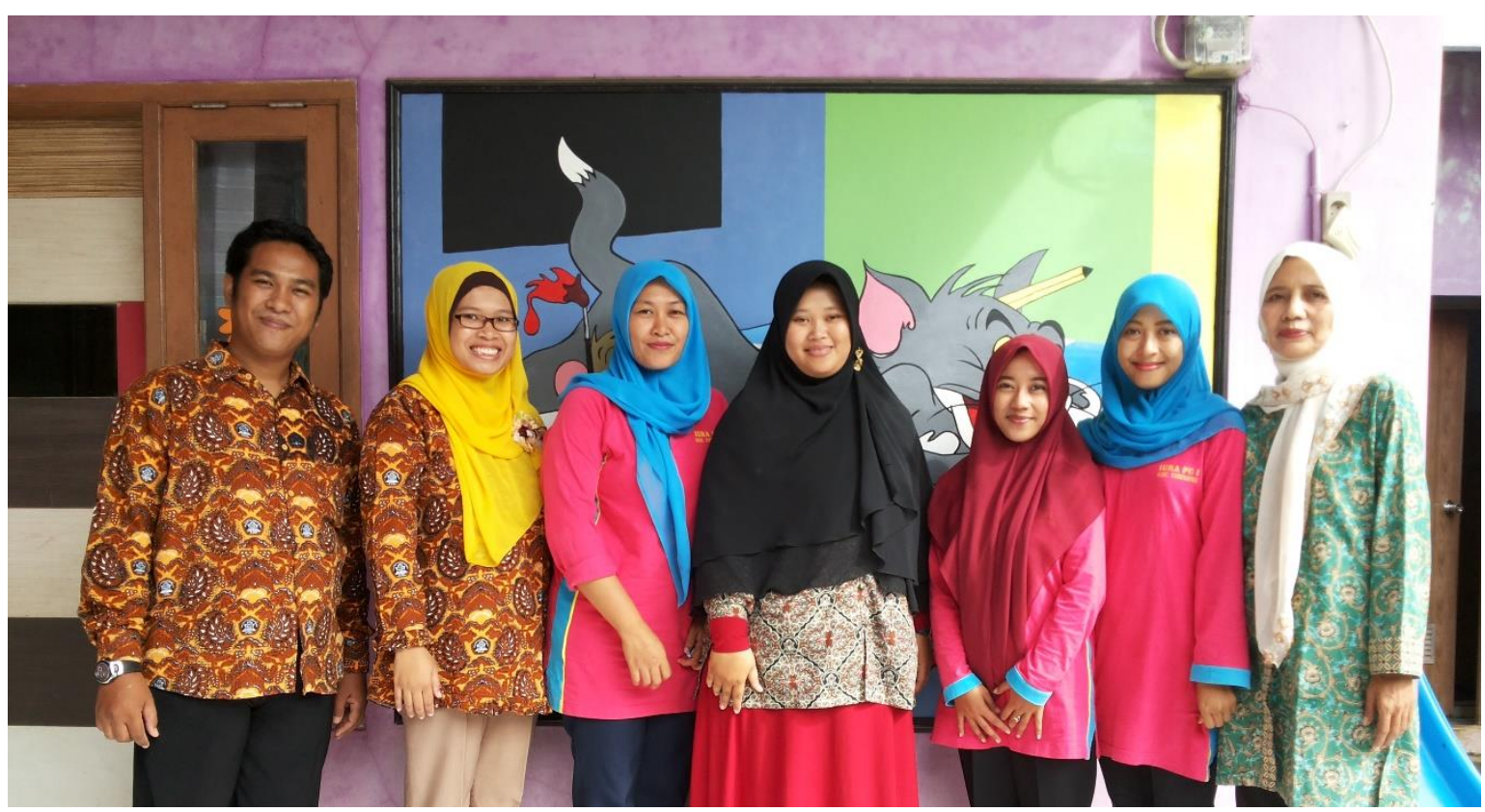

Gambar 3. Dokumentasi kegiatan

\section{Kesimpulan}

Pendidikan karakter pada usia dini merupakan hal yang penting saat ini. Hal ini dikarenakan perkembangan teknologi yang sangat pesat, khususnya dalam penggunaan internet. Sehingga diperlukan sosialisasi kepada pendidik untuk selanjutnya diteruskan kepada orang tua anak didik. Dapat disimpulkan bahwa: Pentingnya pendampingan orang tua atau pendidik tentang penggunaan internet dengan benar. Dampak positif dari internet adalah informasi materi pembelajaran baru untuk anak sedangkan dampak negatifnya adalah internet menyediakan informasi tentang budaya asing ataupun informasi yang belum layak diterima anak didik usia dini. Dampak negatif ketika menggunakan internet melalui Smartphone dapat mempengaruhi perkembangan anak didik.

\section{Daftar Pustaka}

Claretta, D., \& Arianto, I. D. (2018). Pendampingan Ibu pada Anak Dalam Penggunaan Internet. Jurnal IImu Komunikasi, 16(2), 129. https://doi.org/10.31315/jik.v16i2.2689

Damanik, S. W. H., \& Purba, R. (2021). Strategi Pola Asuh Pendidikan Anak Usia Dini di Masa Pandemik Covid-19 Pada Paud Ar Raudah. BERNAS: Jurnal Pengabdian .... https://ejournal.unma.ac.id/index.php/bernas/article/view/688

Desa, D. I., Barat, K., Palar, J. E., \& Oroh, W. (2018). Hubungan Peran Keluarga Dalam Menghindari Dampak Negatif Penggunaan Gadget Pada Anak Dengan Perilaku Anak Dalam Penggunaan Gadget Di Desa Kiawa 2 Barat Kecamatan Kawangkoan Utara. Jurnal Keperawatan, 6(2).

Dhahir, D. F. (2018). Pola Asuh Penggunaan Internet di Kalangan Anak-anak Indonesia. Jurnal Pekomnas, 3(2), 169-178. https://media.neliti.com/media/publications/267630-internetparenting-upon-indonesian-child-a9a00e70.pdf

Febrino. (2017). Tindakan Preventif Pengaruh Negatif Gadget Terhadap Anak. Noura, 1(1), 1-21.

Khotijah, S. (2013). Pembatasan Penggunaan Internet Pada Anak-Anak Di Bawah Umur. 6(3), 241-252.

Levani, Y., Hakam, M. T., \& Utama, M. R. (2020). The Potential Addiction of Internet Use in 
Indonesian Adolescents in the Early Period of the Covid-19 Pandemic. Hang Tuah Medical Journal, 17(2), 102.

medical.hangtuah.ac.id/index.php/jurnal1/article/view/437/89

http://journal-

Nurgiansah, T. H. (2021). Pelatihan Penelitian Tindakan Kelas Bagi Guru Pendidikan Kewarganegaraan Di Sekolah Menengah Atas Se-Kabupaten Bantul. BERNAS: Jurnal Pengabdian Kepada .... https://www.ejournal.unma.ac.id/index.php/bernas/article/view/566

Sari, A. P., Ilyas, A., \& Ifdil, I. (2017). Tingkat Kecanduan Internet pada Remaja Awal. JPPI (Jurnal Penelitian Pendidikan Indonesia), 3(2), 45. https://doi.org/10.29210/02018190

Ulinnuha, M. (2013). Melindungi Anak Dari Konten Negatif Internet: Studi Terhadap Peramban Web Khusus Anak. Sawwa: Jurnal Studi Gender, \&(2), 341. https://doi.org/10.21580/sa.v8i2.661

Warisyah, Y. (2015). Prosiding Seminar Nasional Pendidikan Pentingnya "Pendampingan Dialogis" Orang Tua Dalam Penggunaan Gadget Pada Anak Usia Dini. Proseding Seminar Nasional Pendidikan, 2016(November 2015), 130-138. http://seminar.umpo.ac.id/index.php/semnasdik2015/article/download/212/213 